\title{
MACROECONOMIC BUSINESS ENVIRONMENT AND THE DEVELOPMENT OF SMALL AND MEDIUM ENTERPRISES IN NIGERIA
}

\begin{abstract}
The study evaluates the effect of the global macro-economic business environment on the development of Small-Scale and Medium-Sized Enterprises (SMEs) in Nigeria. Secondary data on the global macro-economic index of SMEs businesses were selected over 35 years (1985-2019). The data collected were analysed using descriptive statistics and multiple regression analysis techniques. The study revealed the positive coefficient value of 354836.6525 and 24141873.6 for the gross domestic product (GDP) on Purchasing Power Parity (PPP) and Budget variables. A negative coefficient value of -16347085.61 and -232997.0657 was obtained for the inflation rate and the exchange rate, respectively. The coefficient values show the level at which the development of SMEs businesses was affected through the global environmental factors. The study concluded that the global macroeconomic business environment directly affects the development of SMEs businesses. The study recommends a policy strategy that will face out the global macro-economic constraints affecting SMEs businesses.
\end{abstract}

Keywords: business, environment, inflation rate, small and medium enterprises.

\section{INTRODUCTION}

The small-scale and medium-sized enterprises (SMEs) are the commercial business activities developed to generate revenues and economy of the nations within their business environment. There is no organisation that can survive without upholding a good affiliation with its environment. This applies to business as an entity because for any business to thrive there must be a symbiotic relationship with its environment. However, the environment could be the local or international business environment (Ayedun \& Olufowobi, 2016). This environment is a multi-dynamic environment in which business organisations have

\footnotetext{
${ }^{1}$ Moruff Sanjo Oladimeji, Dr, Department of Business Administration, Olabisi Onabanjo University, Ago-Iwoye, Ogun State, Nigeria; e-mail: moruff.oladimeji@ oouagoiwoye.edu.ng. (corresponding author). ORCID: 0000-0001-7342-3117.

${ }^{2}$ Nurudeen Afolabi Sofoluwe, Dr, Department of Cooperative and Rural Development, Olabisi Onabanjo University, Ago-Iwoye, Ogun State, Nigeria; e-mail: sofoluwe.nurudeen@ oouagoiwoye. edu.ng. ORCID: 0000-0003-2566-4340.

${ }^{3}$ Henry Adewale Odunaya, Dr, Department of Economics, Adeniran Ogunsanya College of Education, Oto-Ijanikin, Lagos, Nigeria. ORCID: 0000-0003-2744-1319.
} 
considerable influence on their business. These environments are pertinent to form the business outlooks of an organization and their magnificent constraint on the development of SMEs in Nigeria. The environmental restraint concentrated here is Gross Domestic Product (GDP) or Per Capital income on Purchasing Power and Parity (PPP), inflation rate, budgets, and an exchange rate that affect the operating activities of SMEs businesses in Nigeria (Ajayi, 2016).

The development of SME businesses was precisely related to the sustainability of the global macro-economic business environment. SMEs have been recognized all over the globe as a catalyst for the developing socio-economy of a nation. This was an instrument for attaining macro-economic objectives and sustainable development (Aribaba, Ahmodu \&Yusuff, 2018). The development of SMEs has come to stay in the economic growth of a developing country like Nigeria (Obasan, 2014). Small-Scale and Medium-sized Enterprises play significant roles in an emerging and developed economy in the process of socio-economic changes and development. Apart from the swelling per capita income on purchasing power parity, SMEs generate employment opportunities, enhance regional economic stability through manufacturing dispersion and promote effective utilization of the resource in considering economic development (Aribaba, Ahmodu, Oladele, Yusuff \& Olaleye, 2019).

In the sub-Saharan African continent, Nigeria is the most populous nation with a leading economic success. Therefore, understanding the relevance of SMEs to the country is important to drive the economic activities of Africa. In Nigeria, SMEs are dealing with intensified global challenges; new emerging technologies in ICT, the production process, and an increasing factor of production which affect the export attractiveness. The study reviewed both conceptual and empirical literature on the global business environment and SMEs development in Nigeria. The gaps identified from the literature show that several studies have been conducted, but none was able to indicate the extent to which the exploratory variables of the business environment were examined on the effect of SMEs development from the global perspective. It is, therefore, evaluating the effect of the global macro-economic business environment on the development of SMEs in Nigeria with the emphasis on the following global parameters which include; the gross domestic product or per capita income (PPP), inflation rate, budget, exchange rate, and SMEs. Also, the pertinent question is; "what effect does the global macro-economic business environment has on the development of SMEs in Nigeria"? Conversely, the links between the global macro-economic business environment and its effect on the development of SMEs are vague in the literature. But in the Nigerian milieu, the development of Small and Medium Enterprises is apparently not effective. Indeed, SMEs businesses play significant roles to boost the nation's economy by availing them adequate facilities.

\section{LITERATURE REVIEW}

\subsection{Small and Medium Scale Enterprises (SMEs)}

Small and medium scale enterprises have long been identified as an instrument of economic growth and development. Although the importance of small and medium scale enterprises has not been questioned, the classification of enterprises into large and medium scale is unfortunately subjective and based on different value judgments. Ayyagari, Beck, and Demirguc-kunt (2003), and Buckley (1989) argues that "the definition of small and medium scale enterprises varies by context, author, and countries". 
In Nigeria, related definitions have been adopted to identify SMEs in the national economy. The Central Bank of Nigeria (CBN), as part of its Small and Medium Enterprise Credit Guarantee Scheme (SMECGS), defines SMEs as an enterprise with assets (excluding land) of between N5million and N500million and between 11 and 300 labour force. The National Council of Industry in 2011 set the limit at 300 employees and the asset base of N200 million excluding land. The national policy on small and medium enterprises also defined SMEs according to employment and assets. A micro-enterprise is defined as a business with less than 10 employees and an asset base of less than N5million. A small enterprise has between 10 and 49 employees and its assets are between N5 and N50 million while a medium enterprise has 50 to 199 employees and an asset base of between N50 million and N500 million (Folorunsho, 2015).

More generally and more broadly, Ogechukwu (2006) presented some general criteria for defining small and medium-sized scale enterprises in different countries. These include the number of employees, annual turnover, local operations, sales volume, financial strength, manager and owner autonomy, relatively small markets relative to their industries, and capital usually provided by individuals or shareholders.

\subsection{Small and Medium Scale Enterprises Development}

Small and medium-scale enterprises are sub-sectors of the industrial sector that play a vital role in industrial development. Ojo (2009) argued that one of the answers to development challenges in developing countries, particularly in Nigeria, is the support of entrepreneurial development system. The performance and effectiveness of small and medium-scale enterprises as instruments of economic growth and development in Nigeria have long been examined. Despite the government institutional policies to build the capacity of small and medium-scale enterprises, small and medium-scale enterprises have not met expectations. This has raised serious concerns and doubts about the ability of SMEs to stimulate economic growth and national development in Nigeria.

Aminu, Adamu, and Ibrahim (2018) observed that numerous studies have shown that small and medium scale enterprises act as a catalyst for a growth and development of a national economy this was supported by Anthony and Arthur (2008), Chinweuba and Sunday (2015), and Vijayakumar (2013). Chinweuba and Sunday (2015) opined those SMEs activities are growth enhancing through expansion in output and other various means of survival. Motilewa, Ogbar and Aka (2015) also established that SMEs are found to be engine of growth in Nigeria. The challenge of solving the problems of hunger, poverty and unemployment is even more worrying if we consider the achievement of the Millennium Development Goals by the country in 2025. If Nigeria wants to achieve the Millennium Development Goals by 2025 , one of the sure ways is to improve the capacity of its SMEs.

\subsection{Macroeconomic business environment}

Macro environment are the general environment within the economy that affects all the business groups at the same time in term of the working, performance, decision making and strategy. It is not static and so it keeps on changing and fluctuating. They are the outside forces that are not under the control of the firm. It consists of individuals, groups, organizations, agencies and others with which the firm deals during the course of its business. They are classified into economic, social, technological, political and legal, and demographic. The ability of a company to design and adjust its internal variables to take advantage of the opportunities offered by the external environment and its ability to control 
the threats posed by the same environment determine its success (Parker, 2017). A more punctual perspective represents the environment, as a global uncontrollable force, to which the company must adapt its policies and that is made up of participants and external forces that influence the possibilities of companies to develop and maintain profitable transactions (Kotler, 1998). The macroeconomic business environment deals with the economic aspect of the business environment which include gross domestic product, inflation rate, budget and exchange rate.

\subsection{Theoretical Review}

\subsubsection{Supporting Theories of Global Business Environment}

\subsubsection{The Systems Theory}

A system is a set of interrelated and interdependent parts arranged to produce a unified whole. Systems theory sees an organization as a system that must function harmoniously not only in itself but also in a variety of other systems. Therefore, it must also work in harmony with the other systems around it. Mele, Pels, and Polese (2010) explain a system as an entity, which is a coherent whole such that a boundary is perceived around it in order to distinguish internal and external elements and to identify input and output relating to and emerging from the entity. Scholars such as Burns and Stalker (1961), Lawrence and Lorsch, (1967), Aldrich, (1979) have adopted - implicitly or explicitly - a vision of organizations as systems with the aim of analyzing the relationship between organizations and their environment

The application of open system to the organization is advanced by Katz and Kahn (1966), Mele et al. (2010). The organization is seen as a system built by energetic inputoutput where the energy coming from the output reactivates the system. Social organizations are then open systems due to their material exchanges with the environment. Emery and Trist (1960) address organizations as socio-technical systems, underlining the two main components of the firm seen as a system: a social component (people), and a technical component (technology and machines).

\subsubsection{Location Specific Advantage Theory}

The theory according to Amarasena, (2017) focuses on the location specific advantages of the foreign market which are mainly categorised as availability of resources and lack of political obstructions for investments. Amarasena, (2017) opined that for a firm to start its foreign businesses, it is better for such firm to have more of foreign location advantages than the home country of operation. This was also supported by Franko, (1971), Sharma and Johanson, (1987). Ozga (1960) argued that location theory could explain why MNEs emerge. Supply oriented location theory and demand oriented location theory are the two folds that emerged in location theory. Supply oriented location theory argues that production takes place where the factor costs for production and distribution are the lowest. Whereas, demand oriented location theory argues that the location of a firm is governed by the location of its market and competitors. The emergence of MNEs was as a result of four location factors which are: raw materials, cheap labour, protected and untapped markets, and transportation costs. Dunning (1973) opined that this actually gave good insights into the understanding of geographical distributions of MNEs. 


\subsubsection{Supporting Theories of Small-Scale Enterprises}

Schumpeter (1949) was the first to advocate a dynamic theory of entrepreneurship that views entrepreneurship as the catalyst that disrupts the stationary circular flow of the economy and thus initiates the process of development. An innovator who introduces new products or services into the economy receives the status of entrepreneur. Schumpeter is the first great theorist to place the human factor at the heart of the process of economic development.

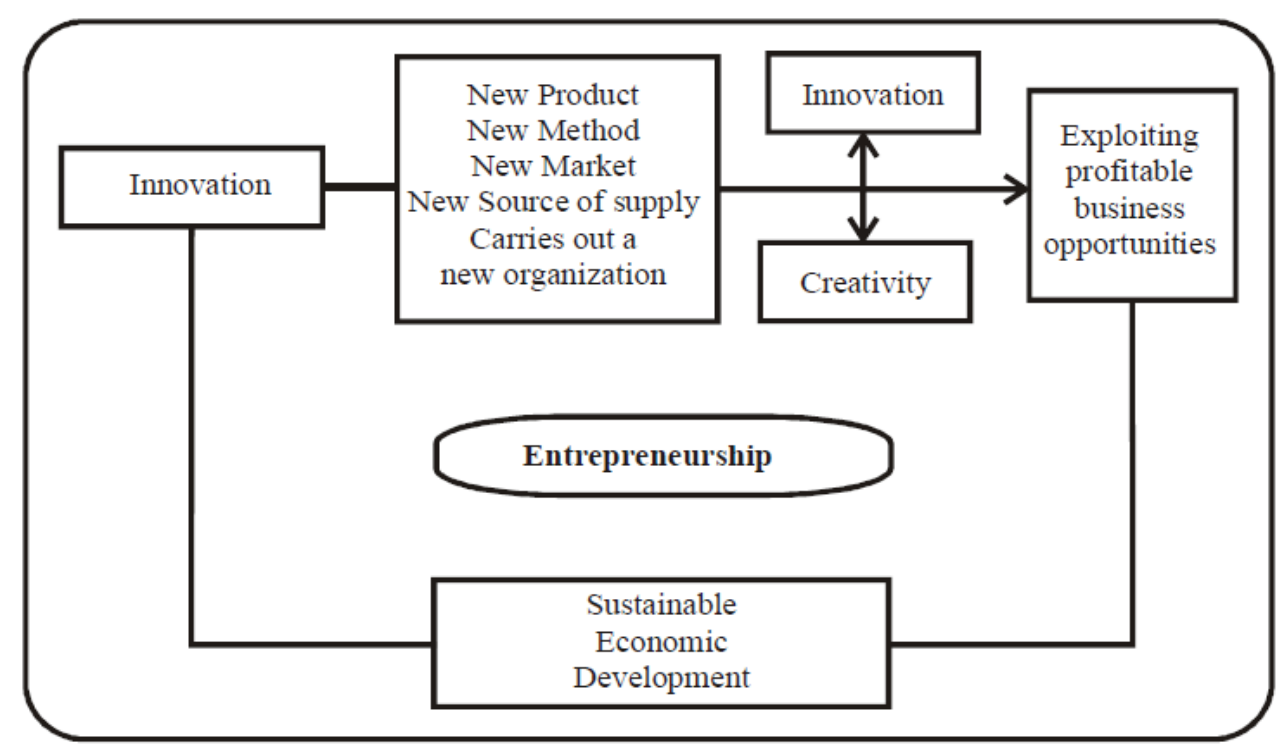

Figure 1. Innovation Theory of Entrepreneurship

Source: (Schumpeter, 1949)

The main figure of this theory, "the innovative entrepreneur", has played an important role in the rise of modern capitalism. The entrepreneur has been the main driver of the economic development process. On the side of criticism, this theory seems biased because it puts too much emphasis on innovative functions. He ignores the risk-taking and organizational aspects of entrepreneurship. An entrepreneur must not only innovate, but also pool resources and use them optimally. Despite these lacking, the theory supports the "entrepreneurial spirit" of entrepreneur to innovate. It is the act that gives resources a new capacity to create wealth. Innovation, in fact, creates a resource. This gives it an economic value." Schumpeter's views are particularly relevant in developing countries where innovations need to be encouraged. The transformation of an agrarian economy into an industrial economy has required many initiatives and changes on the part of businessmen and managers.

McClelland (1961) highlighted the characteristics of the entrepreneur to include (i) to do things in a new and better way and (ii) decision-making in uncertainty. McClelland (1961) society proposed a theory based on his research that entrepreneurship ultimately depends on motivation. It is the need for accomplishment (N-Ach), the sense of doing-- and 
getting things done, that promote entrepreneurship. According to him, N-Ach is a relatively stable personality characteristic rooted in childhood experiences through family socialization and child learning practices that emphasize standards of excellence, material warmth, self-reliance training and low father dominance.

\subsection{Empirical Review}

Obasan, (2014) in his empirical study adopted the qualitative method of research and concludes that competition, inflationary trend, technological changes, government policies, accessibility of infrastructural facilities, change in consumer behaviour and income are the problems posed to SMEs managers. SMEs businesses in Nigeria are the victims of the Nigeria environment. This was proven by the President Buhari administration and made the environment hostile for SMEs (Sheu \& Mahmood, 2014).

Ayedun and Awoyemi (2014) averred that internal and external environment of businesses could be properly analysed through the use of proper environmental scanning for the enterprise to have a competitive advantage. This is imperative for business environment on the survival of SMEs because without adequate conducive environment, no business will strive. The government intervention supports could be loan, grants or other social intervention supports facilities to support SMEs businesses and enhance the improvement of socio-economic development of a nation (Adeoye, 2013).

Eruemegbe (2015) posits that among the top ten critical factors that greatly affect the business productivities in Nigeria are not from the external environment. Therefore, internal environment also contributed to the failure of SMEs businesses in Nigeria because the failure of business manager and the workers to work expeditiously in an environment would also reflect on the part of business. These were corroborated in cross-sectional research of a selected economic variable with the confirmation of the highly influenced decision of management of a firm. Specifically, the devaluation of currency and energy resources will discourage a country without adequate infrastructural facilities and face-off some SMEs businesses that are not financially capacitated (Dionco-Adetayo \& Adetayo, 2003). Research conducted by Adeoye (2012) was shown that environmental changes are continuously exerting new pressures on companies' performance. In adopting these changes, companies will need to formulate and implement a strategy to reform the business productivities.

Kujala (2015) examined the process of internationalization of an enterprise in the clothing and textile manufacturing sector in Ghana. The study adopted a qualitative approach, using a longitudinal method involving primary and secondary data and an analysis of critical events. The results of the study showed the high level of competition expected of small emerging market operating in the clothing and textile manufacturing industry. Indris and Primiana (2015) conducted a study on the analysis of the internal and external environment of the performance of small and medium industries (SMEs) in Indonesia. The study used a secondary source of data collection through the use of available literature on internal and external performance analyses of small and medium-sized industries (SMEs). The theoretical results of the study showed that the analysis of the internal and external environment had a significant impact on the performance of small and medium-sized industries (SMEs) in Indonesia. 


\section{METHODOLOGY}

The study adopts an ex-post-facto research design for the study. Data were sourced from the Central Bank of Nigeria (CBN) Statistical Bulletin and Nigeria Bureau of Statistics which makes it principally a secondary source of data. The data collected for this study form the basis of the study that covers 35-years between the periods of (1985 - 2019). The study employs a number of analytical tools based on the objectives of the study which includes: descriptive statistics and regression analysis. Engel and Granger Cointegration test was also carried out know if there is long-run movement among the variables in the SMEs.

\subsection{Model Specification}

Diverse of models have been used to examine the effect of global macro-economic business environment on the development of SMEs in Nigeria but the study adapted Utile, Okwori and Ikpambese (2018) model which was re-modified to determine the effect of macroeconomic business environment on the development of SMEs in Nigeria. In that regard, the study therefore navigates a model to guide its analyses. The model is as follows:

$$
\text { SMEs }=\mathrm{f}(\text { GDP }, \text { INF, BUDG, EXCH })
$$

This research would specify the above model in econometric form as follows:

$$
S M E s=\beta 0+\beta 1 \mathrm{GDP}+\beta 2 \mathrm{INF}+\beta 3 \mathrm{BUDG}+\beta 4 \mathrm{EXCH}+\varepsilon_{i t}
$$

Where:

SMEs = Small-Scale and Medium-Sized Enterprises

GDP = Gross Domestic Product or Per Capital Income based on Purchasing, Power and Parity

$\mathrm{INF}=$ Inflation Rate

BUDG = Budget

$\mathrm{EXCH}=$ Exchange Rate

$\beta_{0}=$ intercept

$\beta_{1-4}=$ coefficient of explanatory variables

$\varepsilon_{\mathrm{it}}=$ Stochastic error term to represent other explanatory variables not mentioned in research.

The a priori expectation of the parameters are:

$$
\beta 1>0 ; \beta 2>0 ; \beta 3>0 ; \beta 4>0
$$

\section{RESULTS AND DISCUSSION OF FINDINGS}

\subsection{Descriptive Statistics of the study variables}

The descriptive statistics of the Table 1 displays the mean, minimum, maximum, mid value; and the normality of the variables. The mean values of 1 macroeconomic business environment variables are $3762.33,19.32,21.41$ and 112.71 respectively. This shows that there is a difference between the macroeconomic business environment variables and the development of SMEs in Nigeria. Thereby, revealing some degree of realistic effect, the macroeconomic business environment has on the development of SMEs. The positive 
kurtosis value indicates the level at which the macroeconomic business environment affects the development of SMEs while the negative kurtosis value represents the flatter peak effect of the normal distribution. The mean values of all the explanatory variables are positively skewed except the GDP variable with the value of -0.63 . The skewness describes the positive and negative value of symmetric data as its affect the development of SMEs in Nigeria. The confidence level of $(95 \%)$ is an indication that the majority of the variables are positively distributed.

Table 1. The Descriptive Statistics Output

\begin{tabular}{|l|c|c|c|c|c|}
\hline & SMEs & GDP & INFR & BUDGET & EXCHR \\
\hline Mean & 2729038086 & 3762.335 & 19.317 & 21.413 & 112.711 \\
\hline Standard Error & 232618069.5 & 252.617 & 3.030 & 4.076 & 18.502 \\
\hline Median & 2226699000 & 3565 & 12.09 & 10.06 & 118.55 \\
\hline Mode & - & 3069 & - & 10.06 & 21.89 \\
\hline Standard Deviation & 1376187058 & 1494.502 & 17.927 & 24.112 & 109.461 \\
\hline Sample Variance & $1.89389 \mathrm{E}+18$ & 2233535.546 & 321.3654328 & 581.407 & 11981.778 \\
\hline Kurtosis & -0.618 & 0.039 & 1.965 & 1.401 & 0.883 \\
\hline Skewness & 0.731 & -0.629 & 1.776 & 1.479303515 & 1.168 \\
\hline Range & 5104152100 & 5505.76 & 67.46 & 89.02 & 368.01 \\
\hline Minimum & 860643300 & 549.24 & 5.38 & 1.1 & 1 \\
\hline Maximum & 5964795400 & 6055 & 72.84 & 90.12 & 369.01 \\
\hline Sum & 95516333015 & 131681.72 & 676.1 & 749.46 & 3944.87 \\
\hline Count (YEARS) & 35 & 35 & 35 & 35 & 35 \\
\hline $\begin{array}{l}\text { Confidence Level } \\
\text { (95.0\%) }\end{array}$ & 472736794.5 & 513.379 & 6.158 & 8.283 & 37.601 \\
\hline
\end{tabular}

Source: Author's calculation.

\subsection{Regression Analysis}

The result of the Engle and Granger co-integration test shows that there is long-run movement among the variables in the SMEs model. This is evidence from the Augmented Dickey-Fuller test statistic that shows a level stationary result at 5\% significance level. This result indicates that all variables have long-run co-movement and forecasting ability (Table 2).

Table 2. Co-integration Test

\begin{tabular}{|c|c|c|c|}
\hline \multicolumn{3}{|c|}{ Engel and Granger Co-integration Result } & \multirow[b]{2}{*}{ Prob.* } \\
\hline & & t-Statistic & \\
\hline \multicolumn{2}{|c|}{ Augmented Dickey-Fuller test statistic } & -4.1789 & 0.0001 \\
\hline \multirow[t]{3}{*}{ Test critical values: } & $1 \%$ level & -2.635 & \\
\hline & $5 \%$ level & -1.951000 & \\
\hline & $10 \%$ level & -1.610907 & \\
\hline \multicolumn{3}{|c|}{ *MacKinnon (1996) one-sided p-values. } & \\
\hline
\end{tabular}

Source: Author (2020). 
The result of the implied ECM as shown in the Table 3 indicates that the variables can adjust automatically in the short-run within 13.4 years. This is evidence from the negative and significant coefficient of ECM $(-0.3817, \mathrm{p}<0.05)$. The coefficient of GDP is positive and statistically insignificant at $5 \%$ level, indicating that $1 \%$ increase in gross domestic product in Nigeria has no significant contribution to the growth of SMEs in the short-run. Also, the coefficients of GBDG, exchange rate and inflation rate are negative and insignificant at 5\% level, implying that all these variables have no significant short-run influence on the growth of SMEs in Nigeria. Although, the model is statistically significant at $5 \%$ level (evidence from the value of F-statistic) and has no serial correlation problem as shown in the result of Durbin-Watson statistic.

Table 3. Implied Error Correction Mechanism Result

\begin{tabular}{|c|c|c|c|c|}
\hline \multicolumn{5}{|l|}{ Dependent Variable: DLOG(SMES) } \\
\hline Variable & Coefficient & Std. Error & t-Statistic & Prob. \\
\hline C & 0.041553 & 0.036190 & 1.148187 & 0.2606 \\
\hline EG(-1) & -0.381699 & 0.146979 & -2.596962 & 0.0148 \\
\hline DLOG(GDP) & 0.075808 & 0.097333 & 0.778856 & 0.4426 \\
\hline DLOG(GBDG) & -0.027006 & 0.080697 & -0.334661 & 0.7404 \\
\hline D(EXH) & -0.001519 & 0.001150 & -1.320932 & 0.1972 \\
\hline D(INF) & -0.003102 & 0.002629 & -1.179843 & 0.2480 \\
\hline R-squared & 0.357659 & F-statistic & 3.118107 \\
\hline Adjusted R-squared & 0.242955 & Durbin-Watson stat & 1.532657 \\
\hline
\end{tabular}

Source: Author (2020).

Table 4 shows the estimated long-run SMEs model. The result shows that the explanatory power of the model explains almost $70 \%$ of the total variations in the growth of SMEs while $30 \%$ of the total variations are unexplained. This indicates that the model has high goodness of fit. The model is statistically significant at $5 \%$ level as evidence from the value of F-statistic $(20.94>9.48)$. The model is also free from serial correlation problem since the value of Durbin-Watson statistic is close to 2 . The long-run coefficient of GBDG is positive and statistically significant at 5\% level implying that $1 \%$ increase in GBDG would result to $0.23 \%$ increase in SME growth. Thus, GBDG significantly increase the growth of SMEs in the long run. The coefficient of inflation is negative and statistically significant at $5 \%$ level. This indicates that in the long run, as price of goods increases by $1 \%$, the growth of SMEs decreases by $0.011 \%$. Hence, increase in price of goods significantly deters the growth of SMEs in Nigeria. The coefficients of gross domestic product and exchange rate are positive and statistically insignificant at 5\% level. This indicates that $1 \%$ increase in both gross domestic product and rate of dollar to naira exchange in Nigeria has no significant change in the growth of SMEs in the long run. The findings commensurate with the findings of Aribaba et al (2019). 
Table 4. Long-run Result

\begin{tabular}{|c|c|c|c|c|}
\hline \multicolumn{2}{|l|}{} & & \\
\hline Dependent Variable: LOG(SMES) & Coefficient & Std. Error & t-Statistic & Prob. \\
\hline Variable & 21.172 & 0.782 & 27.073 & 0.0000 \\
\hline C & 0.003 & 0.102 & 0.030 & 0.976 \\
\hline LOG(GDP) & 0.232 & 0.084 & 2.758 & 0.009 \\
\hline EXH & 0.001 & 0.001 & 0.636 & 0.529 \\
\hline INF & -0.011 & 0.003 & -3.756 & 0.001 \\
\hline R-squared & 0.736 & F-statistic & 20.942 \\
\hline Adjusted R-squared & 0.701 & \multicolumn{2}{l}{ Durbin-Watson stat } & 1.640 \\
\hline
\end{tabular}

Source: Author (2020).

\section{CONCLUSIONS}

Globalization has made the economy of a nation becomes more exposed to any unfavourable events since the markets are becoming less segmented. The myriad of challenges postured by the country has experienced the vapours of recession as businesses were decelerating; productions were shrinking, unemployment rate upsurges, and capital streams stalled. These affect the SMEs to a large extent in terms of trading and supplying products to other businesses. The study, therefore, recommends that the government should formulate a policy support strategy that will face out the global macro-economic constraints stood on the development of SMEs businesses in Nigeria. They also need to stimulate demand and create an enabling market environment structure through government procurement policies. These will aid in the development of SMEs globally.

The findings of the study lead to the conclusion that most macroeconomic variables do not have a significant effect on the growth of SMEs in the short-run. Consequently, SMEs are more affected by microeconomic factors in the short run. However, statistical evidence indicates that the growth of SMEs is significantly affected in the long run. SMEs are more likely to witness declining growth with an increase in the level of prices over a period of time. This result calls for government intervention on the long-term sustainability of SMEs in developing economies. More importantly, an appropriate framework to regulate inflation will lead to an increasing growth of SMEs in the long run.

\section{REFERENCES}

Adeoye, A. O. (2012). Impact of external business environment on organisational performance of food and beverage industry in Nigeria. "British Journal of Arts and Social Sciences", $6(2)$.

Adeoye, M. O. (2013). The impact of business environment on entrepreneurship performance in Nigeria computing information systems, "Development Informatics and Allied Research", 4(4).

Ajayi, A. (2016). Impact of external business environment on organisational performance of small and medium scale enterprises in Osun State, Nigeria. "Scholedge International Journal of Business Policy and Governance”, 3(10).

Aldrich, H. (1979). Organization and Environment. Prentice-Hall: Englewood Cliffs. 
Amarasena, A. (2017). Current Trends in the International Business Environment. "Universal Journal of Management", 5(8).

Aminu, B., Adamu, J., Ibrahim A. (2018). Impact of Small and Medium Scale Enterprises on Economic Growth: Evidence from "Nigeria Global Journal of Economicsand Business", Vol. 4, No. 2.

Aribaba, F. O., Ahmodu, O. A., Oladele, R., Yusuff, S. A. Olaleye, B. R. (2019). The role of deposit money banks' loan facilities in financing small and medium-scale businesses in Nigeria. Academic Journal of Interdisciplinary Studies", 8(2).

Aribaba, F. O., Ahmodu, O. L., Yusuff, A. S. (2018). An empirical study of cooperative societies on credit de livery for small and medium scale businesses in Ondo State. "Nigeria, Singaporean Journal of Business, Economics and Management Studies, 6(8).

Ayedun, T. A., Awoyemi, A. T. (2014). Environment and enterprise survival: An appraisal of cyber café industry in Ondo State. International Journal of Advanced Studies in Business Strategies and Management (IJASBSM), 2(1).

Ayedun, T. A., Olufowobi, A. (2016). Economic recession and survival strategies of fast food outlets in Ondo State, Nigeria. "International Journal of Advance Research in Social Sciences, Environmental Studies and Technology", 2(1).

Anthony, L., Arthur, S. (2008). The role of micro, small and medium enterprises in economic growth: across-country regression analysis. United States Agency for International Development Micro-Report, No. 135.

Burns, T., Stalker, G.M. (1961). The management of innovation. London: Tavistock.

Chinweuba, E.T., Sunday, C.O. (2015). Quantitative analysis of the impact of small and medium scale enterprises on the growth of Nigerian economy: (1993-2011). "International Journal of Development and Emerging Economics", 3(1).

Dunning, J. H. (1973). The determinants of international production, "Oxford Economic Papers", Vol. 25.

Dionco-Adetayo, E. A., Adetayo, J. O. (2003). Business environment analysis: Globalisation era of imperative for small scale industries. "Journal of Social Sciences”, 7(5).

Emery, F. E., Trist, E. L. (1960). Socio-Technical Systems. Management sciences, models and technique, C.W and others Churchman. London: Pergamon.

Eruemegbe, G. O. (2015). Impact of business environment on organisation performance in Nigeria: A Study of Union Bank of Nigeria. “European Scientific Journal Special Edition”.

Franko, L. G. (1971). Joint Venture Survival in Multinational Corporations. New Hork: Praeger Publisher.

Indris, S., Primiana, I. (2015). Internal and external environment: Analysis on the performance of small and medium industry (SMEs) in Indonesia. "International Journal of Scientific and Technology Research", 4(4).

Lawrence, P., Lorsch, J. (1967). Differentiation and Integration in Complex Organizations. “Administrative Science Quarterly”, 12.

Katz, D., Kahn, R. L. (1966). The social psychology of organization. New York: Willey.

Kotler, P. (1998). Principiile Marketingului. EdituraTeora, Bucureşti.

Kujala, I. A. (2015). SMEs Internationalisation from an Emerging Market to a Developed Market: A case study from Ghana. An unpublished thesis in International Marketing, Abo Akademi University, Finland, Abo Akademi University Press. 
McClelland, D. C. (1961). The Achieving Society. Van Nostrand Co, Princeton NJ.

MohdKhiruddin, H. (2000). Aproposed strategic framework for SMEs success. "Malaysian Management Review”, 35 (2).

Mele, F., Pels, J., Polese, F. (2010). A Brief Review of Systems Theories and Their Managerial Applications. "Service Science" 2(1/2).

Motilewa, B. D., Ogbari, M., Aka, D. O. (2015). A review of the impacts SMEs as social agents of economic liberations in developing economies. "International Review of Management and Business Research", 4(3).

Obasan, K. A. (2014). The impact of business environment on the survival of small scale businesses in Nigeria. "International Journal of Management and Business Research", 4(3).

Ojo, O. (2009). Impact of Micro Finance on Entrepreneurial Development: A case of Nigeria. A paper presented at the International Conference on economic and administration, organized by the faculty of Administration and Business, University ofBucharest, Romania, $14^{\text {th }}-15$ th November, 2009.

Ozga, S. A. (1960). Imperfect Markets through Lack of Knowledge. "The Quarterly Journal of Economics", Vol. 74, No. 1.

Parker, P. (2017). Global Business Environment. [Access on the internet] http://www. myassignmenthelp.net/global-business-environment.

Porter, M. E. (1990). Competitive strategy: Techniques for analyzing industries and competitors. New York: Free Press.

Schumpeter, J. (1949). Theory of Economic Development. [Access on the internet] www.emeraldinsight.com/

Sharma, D. D., Johanson, J. (1987). Technical consultancy in internationalisation. "International Marketing Review", Vol. 4, No. 4.

Sheu, A. M., Mahmood, R. (2014). The impact of business environment on SMEs performance in Nigeria. "International Journal of Management Sciences", 3(8).

Utile, B. J., Okwori, A. O. Ikpambese, M. D. (2018). Effect of interest rate on economic growth in Nigeria. "International Journal of Advanced Academic Research", 4(1).

Vijayakumar, S. (2013). The trend and impact of SMEs on economic growth of Sri Lanka. "Journal of Global Business Management and Research", 2(1). 
Macroeconomic business environment ...

\section{Annex}

The Table Showing the Data Used:

\begin{tabular}{|c|c|c|c|c|c|}
\hline YEAR & SMEs & $\begin{array}{l}\text { GDP/Per Capital } \\
\text { Income (PPP) }\end{array}$ & $\begin{array}{c}\text { Inflation rate } \\
\%\end{array}$ & $\begin{array}{c}\text { Budget Billions } \\
\text { \& Trillions }\end{array}$ & $\begin{array}{c}\text { Exchange Rate } \\
(\$)\end{array}$ \\
\hline 1985 & 2521649000 & $3,222.69$ & 7.44 & 1.2 & 1 \\
\hline 1986 & 1823270000 & 882.52 & 5.72 & 2.2 & 1.75 \\
\hline 1987 & 1607847000 & 639.01 & 11.29 & 3.2 & 4.02 \\
\hline 1988 & 1733173000 & 598.26 & 54.51 & 4.1 & 4.54 \\
\hline 1989 & 1323240000 & 549.24 & 50.47 & 4.3 & 7.36 \\
\hline 1990 & 1606118000 & 3,361 & 7.36 & 4.6 & 8.04 \\
\hline 1991 & 1611255000 & 3,288 & 13.01 & 5.7 & 9.91 \\
\hline 1992 & 1424518000 & 3,355 & 44.59 & 6.2 & 17.30 \\
\hline 1993 & 860643300 & 3,205 & 57.17 & 6.8 & 22.07 \\
\hline 1994 & 1203093000 & 3,069 & 57.03 & 7.0 & 22.00 \\
\hline 1995 & 1496441000 & 2,992 & 72.84 & 7.3 & 21.90 \\
\hline 1996 & 1661213000 & 3,041 & 29.27 & 8.0 & 21.88 \\
\hline 1997 & 1776028000 & 3,053 & 8.53 & 1.10 & 21.89 \\
\hline 1998 & 1607914000 & 3,055 & 10.00 & 2.60 & 21.89 \\
\hline 1999 & 1634716000 & 2,997 & 6.62 & 2.99 & 92.34 \\
\hline 2000 & 1652325000 & 3,069 & 6.93 & 7.02 & 101.70 \\
\hline 2001 & 1789778000 & 3,170 & 18.87 & 8.94 & 111.23 \\
\hline 2002 & 1964082000 & 3,565 & 12.88 & 10.06 & 120.58 \\
\hline 2003 & 2226699000 & 3,731 & 14.03 & 10.45 & 129.22 \\
\hline 2004 & 2628652000 & 3,974 & 15.00 & 10.19 & 132.89 \\
\hline 2005 & 3143849000 & 4,122 & 17.86 & 10.06 & 131.27 \\
\hline 2006 & 3719532000 & 4,259 & 8.24 & 10.88 & 128.65 \\
\hline 2007 & 4140298000 & 4,421 & 5.38 & 20.03 & 125.81 \\
\hline 2008 & 4939627000 & 4,597 & 11.58 & 20.04 & 118.55 \\
\hline 2009 & 4112168000 & 4,836 & 11.54 & 30.05 & 148.90 \\
\hline 2010 & 2391031000 & 5,085 & 13.72 & 40.04 & 150.30 \\
\hline 2011 & 2925834000 & 5,214 & 10.84 & 40.07 & 153.86 \\
\hline 2012 & 3548488000 & 5,291 & 12.22 & 40.09 & 157.50 \\
\hline 2013 & 4598098000 & 5,495 & 8.48 & 40.99 & 157.31 \\
\hline 2014 & 5477949000 & 5,688 & 8.06 & 40.96 & 158.55 \\
\hline 2015 & 4535702000 & 5,686 & 9.01 & 40.76 & 192.44 \\
\hline 2016 & 3512263000 & 5,449 & 15.68 & 60.06 & 348.12 \\
\hline 2017 & 4154302800 & 5,351 & 16.52 & 70.44 & 369.01 \\
\hline 2018 & 4199741515 & 5,316 & 12.09 & 90.12 & 365.72 \\
\hline 2019 & 5964795400 & 6,055 & 11.32 & 80.92 & 365.37 \\
\hline
\end{tabular}

DOI: 10.7862/rz.2021.mmr.27

The text was submitted to the editorial office: September 2021.

The text was accepted for publication: December 2021. 
